\title{
ANTI-COAGULANT THERAPY IN THE PREVENTION OF VENOUS THROMBOSIS AND PULMONARY EMBOLISM IN THE SPINAL CORD INJURY
}

\author{
By NoRval Watson \\ Spinal Injuries Unit, Lodge Moor Hospital
}

Abstract. A prophylactic regime of subcutaneous low-dose heparin for the Ist month, followed by warfarin for the 2 nd and 3 rd months after spinal cord injury resulted in a dramatic reduction in the incidence of venous thrombosis and pulmonary embolism.

Key words: Spinal cord injury; Venous thrombo-embolism; Prophylactic heparin.

IN 1968 and again in 1974 I reported in our journal Paraplegia and at this meeting, a survey of I 5 years' experience (1958-72) in the management of spinal cord injury with special reference to the incidence of venous thrombosis and pulmonary embolism.

I recorded that there had been an increase over that period in the incidence of venous thrombosis from $12 \frac{1}{2}$ to 17 per cent, of pulmonary embolism from 5 to Io per cent, and of mortality from $I \frac{1}{2}$ to $2 \frac{1}{2}$ per cent (see Table I).

At the time of reporting I did not consider that our incidence of complications justified any change of treating the complications with anti-coagulants as soon as they were detected, but without prophylactic therapy. Our decision seemed justified at that time as the next year, 1973, proved to be a year of very low incidence of venous thrombosis, only 6 per cent, but the only death in that year was a youth of I 9 with a complete dorsal injury, who died suddenly in the 2 nd week with a massive pulmonary embolism. This unfortunate death in a fit young person was followed by a year, 1974, in which the incidence of complications rose higher than ever before to 20 per cent with three deaths, a mortality of 6 per cent, all sudden deaths in elderly tetraplegics (see Table II).

At this time the results of a world wide multi-centre trial of subcutaneous low-dose heparin published in the Lancet proved conclusively that the incidence of

TABLE I

Incidence

\begin{tabular}{|c|c|c|c|}
\hline Period & $\begin{array}{l}\text { Venous } \\
\text { thrombosis }\end{array}$ & $\begin{array}{l}\text { Pulmonary } \\
\text { embolism }\end{array}$ & Mortality \\
\hline 1958-67 & I $2 \frac{1}{2} \%$ & $5 \%$ & $\mathbf{I}_{2}^{1} \%$ \\
\hline I968-72 & I7 & IO & $2 \frac{1}{2}$ \\
\hline $\begin{array}{l}\text { I973-74 } \\
\text { Heparin }\end{array}$ & I 4 & I 2 & 4 \\
\hline I975-76 & 6 & $2 \frac{1}{2}$ & 0 \\
\hline
\end{tabular}


TABLE II

Yearly incidence

\begin{tabular}{ccccc}
\hline Year & $\begin{array}{c}\text { Early } \\
\text { admissions }\end{array}$ & $\begin{array}{c}\text { Venous } \\
\text { thrombosis }\end{array}$ & $\begin{array}{c}\text { Pulmonary } \\
\text { embolism }\end{array}$ & Mortality \\
\hline I973 & 50 & $3(6 \%)$ & $2(4 \%)$ & I $(2 \%)$ \\
I974 & 49 & II $(22 \%)$ & I0 $(20 \%)$ & $3(6 \%)$ \\
Heparin & & & & \\
I975 & 38 & I $(21 \%)$ & $0(0 \%)$ & $0(0 \%)$ \\
I976 & 44 & $4(9 \%)$ & $2(4 \%)$ & $0(0 \%)$ \\
\hline
\end{tabular}

venous thrombosis in postoperative patients was greatly reduced by prophylactic anti-coagulant therapy.

Hachen, at our meeting in I974, had already given evidence that the incidence of venous thombosis and pulmonary embolism had been greatly reduced in cases of spinal cord injury, given low dose subcutaneous heparin followed by oral anticoagulants.

I decided that from the Ist day of 1975 all patients with a recent spinal cord injury would be treated prophylactically from the Ist day of admission. There have been no exceptions to the regime. Our method is to give subcutaneous heparin 5000 units twice daily for a month. During the 4 th week all patients are gradually started on warfarin so that by the time the heparin is stopped, the warfarin is being given in therapeutic dosage to keep the prothrombin time between two to three times normal. The warfarin is continued for 2 months so that the average patient is getting mobilised from bed to chair at the end of the $3 \mathrm{rd}$ month when the anti-coagulant therapy is stopped.

There have been no complications, local or general from the subcutaneous low-dose heparin. The warfarin therapy similarly has caused few problems, but. the dosage required has varied greatly from I to $9 \mathrm{mg}$ daily. We take care not to administer any drugs liable to interfere with the action of warfarin.

I must, however, report the death of one patient, a high tetraplegic of 34 years, who died in the 8th week from intra-abdominal haemorrhage while on warfarin and whose prothrombin time was within agreed limits of twice normal.

Naturally all acute cases undergo the same routine paraplegic management of 2-hourly turns, physiotherapy, catheterisation and regular bowel evacuation. All nursing and physiotherapy staff are on constant watch for alteration in the size and shape of the legs which are measured regularly. The Sonicaid ultra-sound apparatus is used to confirm or refute any clinical signs of thrombosis. If thrombosis occurs while on subcutaneous low-dose heparin, then full treatment with normal doses of heparin followed by warfarin would be instituted.

The results have been dramatic. During the first year, I975, I had not a single case of thrombosis until the last month of the year when one patient developed a partial block of the left femoral vein. This young man had an incomplete paraplegia associated with head, chest and abdominal injuries which I suspected contributed to his thrombosis. He returned to his university studies with an almost normal gait.

The year 1976 was not quite as successful, four cases of thrombosis occurring, but two of these were minor and caused only partial blockage of the femoral vein. 
The remaining cases developed major complications of venous thrombosis and pulmonary embolism in the 2 nd week. One was a youth of $\mathrm{I} 6$ years who recovered rapidly from his embolic episode and who later had no residual oedema of the legs. The other was a huge fat man who had ankylosing spondulitis with a fracture dislocation of the cervical spine and complete quadriplegia. He had a massive pulmonary embolism in the 2 nd week with cardiac arrest, but recovered well. On reflection we considered that the 5000 units of heparin was quite inadequate for such a gross person. He was the only patient to have been nursed in a S-M Egerton electric bed in a 5-year period in our Unit.

Table III confirms our previous experience that in the pre-heparin era there is a higher incidence of complications in complete than incomplete lesions, that there is a higher incidence in dorsal lesions that at other levels, and that most deaths occurred in cervical injuries. In the post-heparin era the incidence of complications is so low that analysis is not required.

With regard to the site of the thrombosis, 70 per cent were in the left leg, Io per cent in the pelvic veins and 20 per cent could not be identified, but there were none in the right leg, in accordance with our previous findings (see Table IV).

\section{TABLE III}

Incidence according to level and type of lesion

\begin{tabular}{|c|c|c|c|c|c|c|c|c|c|c|c|}
\hline & \multicolumn{3}{|c|}{ Cervical } & \multicolumn{3}{|c|}{ Dorsal } & \multicolumn{3}{|c|}{ Lumbar } & \multirow[t]{2}{*}{ Complete } & \multirow[t]{2}{*}{ Partial } \\
\hline & $\mathrm{C}$ & $P$ & Total & $\mathrm{C}$ & $P$ & Total & $\mathrm{C}$ & $P$ & Total & & \\
\hline \multicolumn{12}{|l|}{ I973-74 } \\
\hline $\begin{array}{l}\text { Admissions } \\
\text { Venous }\end{array}$ & 22 & 29 & $5 \mathrm{I}$ & 23 & 2 & 25 & 8 & 15 & 23 & 53 & 46 \\
\hline $\begin{array}{l}\text { thrombosis } \\
\text { Pulmonary }\end{array}$ & I & 4 & 5 & 6 & 0 & 6 & 2 & I & 3 & $9(17 \%)$ & $5(\mathrm{II} \%)$ \\
\hline Embolism & I & 4 & 5 & 5 & 0 & 5 & I & I & 2 & $7(13 \%)$ & $5(\mathrm{II} \%)$ \\
\hline Deaths & I & 2 & 3 & I & 0 & I & 0 & o & o & $2(4 \%)$ & $2(4 \%)$ \\
\hline \multicolumn{12}{|l|}{ I975-76 } \\
\hline $\begin{array}{l}\text { Admissions } \\
\text { Venous }\end{array}$ & 9 & 25 & 34 & I5 & 6 & $2 \mathrm{I}$ & IO & 17 & 27 & 34 & 48 \\
\hline $\begin{array}{l}\text { thrombosis } \\
\text { Pulmonary }\end{array}$ & I & 0 & I & I & 0 & I & 0 & 3 & 3 & $2(6 \%)$ & $3(6 \%)$ \\
\hline Embolism & I & 0 & I & I & 0 & I & 0 & 0 & 0 & $2(6 \%)$ & $0(0 \%)$ \\
\hline Deaths & 0 & 0 & 0 & 0 & 0 & 0 & 0 & 0 & 0 & $0(0 \%)$ & ० $(0 \%)$ \\
\hline
\end{tabular}

TABLE IV

Site of thrombosis

\begin{tabular}{lrll}
\hline Right leg & $0 \%$ & Pelvis & $10 \%$ \\
Left leg & $70 \%$ & Unidentified & $20 \%$ \\
\hline
\end{tabular}


TABLE V

Date of onset of thrombosis

\begin{tabular}{lrr}
\hline Within I week & 2 & 10\% \\
Within I month & I5 & $80 \%$ \\
Within 3 months & 2 & $10 \%$ \\
\hline
\end{tabular}

TABLE VI

Date of onset of pulmonary embolism

\begin{tabular}{lrr}
\hline At same time as thrombosis & Io & $72 \%$ \\
Within I week & 3 & $21 \%$ \\
Within I month & I & $7 \%$ \\
\hline
\end{tabular}

The complications occurred within a month in 90 per cent of cases, the 2nd or 3 rd week being the most common time after injury, again in support of our previous observations (Table V).

Pulmonary embolism occurred commonly without prior warning of venous thrombosis in over 70 per cent of cases as I described previously (Table VI).

Our results demonstrate the efficacy of routine prophylactic anti-coagulant therapy with low-dose subcutaneous heparin in recent spinal cord injuries. We found that the therapy could be given to all patients without exception and that no complications occurred.

\section{SUMMARY}

After many years of a routine of management in which venous thrombosis and pulmonary embolism were treated vigorously after they had occurred, the Sheffield Unit changed to a prophylactic regime using subcutaneous low-dose heparin for the ist month and warfarin for the 2 nd and 3 rd months, with a dramatic reduction in the incidence of complications.

\section{RÉSUMÉ}

La système, qui était utilisée à Sheffield pendant beaucoup d'années, qui voulait dire que la thrombose veineuse et l'émbolism pulmonaire étaient médicamentées vigoureusment après avoir eu lieu, était substitutée à une système qui implique les doses baisses d'Heparin pendant le premier mois et de Warfarin pendant le deuxième mois et le troisième mois, qui aboutant à une réduction du nombre des complications.

\section{ZUSAMMENFASSUNG}

Nach vielen Jahren einer Routinebehandlung, in der venöse Thrombose und pulmonarer Embolismus stark behandelt wurden, nach dem sie aufgetreten waren, wechselte das Krankenhaus in Sheffield zu einer prophylaktischen Behandlung über, in dem man einen Monat lang kleine Dosen Heparin und im zweiten und dritten Monat Warfarin gab, Dadurch wurden komplikationen erheblich reduziert. 


\section{REFERENCES}

Hachen, H. J. (1974). Paraplegia, 12, I76-I87.

KAKKAR et al. (I975). Lancet, ii, 45-5I.

Watson, N. (I968). Paraplegia, 6, I I3-I2I.

Watson, N. (1974). Paraplegia, 12, I97-20I. 